\title{
20. SZÁZADI HÍRES MAGYAR KÖZGAZDÁK
}

\section{FAMOUS HUNGARIAN ECONOMISTS OF THE 20 TH CENTURY}

\author{
Botos Katalin \\ DSc, professor emerita, Szegedi Tudományegyetem, Pázmány Péter Katolikus Egyetem \\ evmkabor@gmail.com
}

\begin{abstract}
ÖSSZEFOGLALÁS
Harminc éve, hogy az MTA posztumusz rehabilitálta néhány korábbi tagját. Korrigálta, amit a politika nyomására 1949-ben elkövetett: megfosztott számos társadalomtudóst akadémiai rangjától és egzisztenciájától. A 20. századi magyar közgazdák jelentős szerepet játszottak itthon, illetve külföldön a gazdaságpolitika alakításában, vagy jeles, elismert elméleti társadalomtudósok voltak. A két világháború között Heller Farkas volt közülük nemzetközileg a legismertebb. Ő a matematikai közgazdaságtant tanította, míg Navratil Ákos a történeti iskola és az institucionalizmus korai híve volt. Varga István mind a Gazdaságkutató Intézet felállításával, mind a forint stabilizálásával, majd 1956-os reformbizottsági szerepével kiemelkedőt alkotott. A hazánkban maradt közgazdászok igen sokat szenvedtek a két diktatúra: a nemzeti szocializmus és a kommunizmus alatt. Az emigránsok viszont fényes karriert futottak be. Egyetemi professzorok, intézetvezetők lettek, még az Amerikai Közgazdasági Társaság elnöke is kikerült közülük. Továbbá hárman angol lordok lettek: Káldor Miklós, Balogh Tamás, Bauer P. Tamás. Polányi Károly jeles, hívő, baloldali közösségi közgazdász volt, Scitovsky Tibornak az Örömtelen gazdaság szerzett hírnevet.
\end{abstract}

\section{ABSTRACT}

It is almost three decades now, that civilian social scientists who had been deprived of their academic ranks were returned their ranks posthumously. Most of the famous Hungarian economists of the $20^{\text {th }}$ century played a role in shaping economic policy, or were famous theoretical scientists either in Hungary or abroad. Farkas Heller was the best-known Hungarian economist internationally at that time. Ákos Navratil was a professor at the Pázmány Péter Catholic University. Heller was a representative of mathematical economics, while Navratil gravitated towards the historical school, and represented the institutionalist approach. István Varga's theoretical and economic policy work is outstanding, both as the creator of the Hungarian 'currency miracle' and as the chairman of the Economic Commission established in 1956. Those scientist who stayed at home suffered under the dictatorships of both communism and national socialism.

Many of those who emigrated during World War II or in 1956 made distinguished careers. Many made it as far as professors or heads of departments, or even Chairman of the American Economic Association, and enjoyed a great deal of international recognition. Three of them became lords in England: Miklós Káldor, Tamás Balogh and Péter Bauer. Károly Polányi was a religious, left-wing, community economist who considered the role of the state to be important. Tibor Scitovsky earned fame with his book The Joyless Economy. 
Kulcsszavak: történelem, gazdasági eszmetörténet, közgazdászok

Keywords: history, history of economic thought, economists

2019-ben lesz harminc éve, hogy a Magyar Tudományos Akadémia korrigálta azt a súlyos méltánytalanságot, amelyet a Rákosi-rendszer idején, 1949-ben - a kommunista hatalom nyomására - elkövetett. 1989-ben posztumusz visszaadták akadémikusi rangjukat az ettől megfosztott polgári társadalomtudósoknak. Ez ugyan a szegénységben, olykor nyomorban elhunyt közgazdászoknak már csak elvi, utólagos jóvátételt jelentett, de az Akadémia becsületének helyreállítása szempontjából mégis jelentős lépés volt.

Közismert ugyanakkor, hogy a világban számos kiemelkedő magyar elme ért el rangos nemzetközi elismerést. Vajon, mi volt a helyzet a világháború után a magyar társadalomtudósokkal?

Legtöbbjük már a háború előtt, itthon is szerepet játszott a gazdaságpolitika alakításában, de számosan külföldön is gyakorlati gazdaságpolitikusok lettek. Voltak azonban kifejezetten elméleti tudósok köztük, akik fogadott hazájuk tudományos életében jeleskedtek.

A történelem folyamán a magyar társadalomtudósok mindkét diktatúrától sokat szenvedtek. Sokakat háttérbe szorítottak, súlyos börtönbüntetésre ítéltek. Söt, egyeseknek a halál jutott osztályrészül. Többen közülük zsidó származásúak voltak. (Fellner Frigyes esetében a kormányzó személyes közbenjárása sem volt elég, hogy a németek el ne hurcolják Mauthausenbe.)

A fasizmus közeledtére számos magyar tudós elhagyta az országot. Nemcsak híres fizikusaink, de közgazdászaink közül is sokan. Nekik többnyire jól alakultak „odakint” a dolgaik. Aki viszont itthon maradt, a ,szocialista” Magyarországon megaláztatás, szegénység lett a sorsa. Majd jött 1956, és a forradalom után ismét elmenekült országunkból sok értékes ember. Ezúttal nem a faji megkülönböztetés, hanem a politikai helyzettől való félelem miatt. A diktatúra nem volt válogatós... Nemre, fajra való tekintet nélkül sújtott le.

A külföldre került magyar társadalomtudósok közül sokan fényes karriert futottak be. Elég csak arra utalni, hogy hárman lordok lettek Angliában: Káldor Miklós, Balogh Tamás és Bauer P. Tamás. A közgazdaságtan különböző ideológiai irányait követő egyéniségek kerültek ki közülük. Káldor Miklós a keynesiánus politika híve volt, s élete végéig küzdött a monetarizmus ellen. Lord Bauert viszont a monetarizmus elveit követő Thatcher-kormányzat avatta Sirré. Balogh és Káldor urakat, ,a rettenetes ikreket” - ahogy kortárs kritikusaik nevezték őket a munkáspárti kabinet javasolta a királynőnek.

Számos közgazdasági, sőt pénzügyi fogalom kötődik magyar közgazdászok nevéhez. Káldor Miklós, Lámfalussy Sándor, Scitovsky Tibor munkássága be- 
épült az egyetemes modern közgazdaságtanba. (Balassa-Samuelson-hatás, Scitovsky-paradoxon vagy a Káldor-Hicks hatékonysági mutató.) De sokan vitték amerikai professzorságig, tanszékvezetésig. Mindenképpen nemzetközileg elismert emberekké váltak. Egyikük, Fellner Vilmos, az Amerikai Közgazdasági Társaság elnöke lett! Balassa Béla a Világbank elismert szakértője volt, a fejlődés, felzárkózás nagy teoretikusa.

A magyar tudósok sokféle irányzatot követtek. Heller Farkas a hagyományos, matematikai közgazdaságtan művelöje volt, Navratil a történeti iskoláé, de számosan közülük az intézményi vagy a viselkedés-gazdaságtani irányzat képviselői voltak. Ennek ellenére tanulságos, hogy ha kellett, együtt tudtak müködni „a haza javára”, például a Varga István által alapított Gazdaságkutató Intézetben.

Heller Farkas a 20. század második felének talán legismertebb és nemzetközileg is jegyzett közgazdász egyénisége volt. Érdeklődése igen hamar a közgazdaságtan felé fordította. A határhaszon-elméletekre kiírt akadémiai pályázatot még pályája elején (1903) megnyerte, s ezzel egyben bele is dolgozta magát az angolszász gazdaságtani iskola módszertanába. Enciklopédikus tudású, hatalmas munkabírású, nagy szorgalmú szakember volt, aki - nagy riválisának, Navratil Ákosnak a megfogalmazása szerint - mindent tudott a szakmájáról, amit a maga idejében tudni lehetett. Ez annál is nagyobb elismerés volt Navratil részéről, mert pályája kezdetén éppen ő volt akadályozója Heller akadémiai karrierjének. Végül Heller Budapesten habilitált, és a Mủegyetemen tanított. Gyakorlati tevékenysége jól megalapozta gazdaságpolitikai felkészültségét. Az egyetemen fontosnak találta, hogy jó tankönyveket bocsásson a hallgatóság részére. Elméleti közgazdaságtanát 1919-ben, Alkalmazott gazdaságtanát 1920-ban rendezte sajtó alá. Míg az első részben a közgazdaságtan fő témaköreivel foglalkozott, a második kötetet ágazati gazdaságtannak tekinthetjük. Könyvei német, angol, spanyol és finn nyelven jelentek meg. A német egyetemeken 1933-ig tankönyvként használták Heller munkáit. Két könyve négy kiadást ért meg Németországban. 1921-ben németül megjelenő könyve olyan népszerü volt a német egyetemeken, hogy 20000 példány fogyott el belőle. Könyvét Ausztráliában is (!) tankönyvként használták. Brazíliában a leánya még 1970-ben is felfedezte egy tananyagként használt könyvét... A közgazdasági elméletek története címü munkája párját ritkította. (Angol fordítása készülőben volt, de a II. világháború bombázásainak áldozatául esett. Odalett, fordítójával együtt.)

Navratil Ákos Hellerrel ellentétben nem a matematikát alapul vevő módszerek híve volt. Átfogó művében, Közgazdaságtanában nem alkalmazta a ceteris paribus elvét, amely a modellalkotáshoz elkerülhetetlen; a jelenségeket komplexebb hatások eredőjében elemzi. Nem fogadta el kritikátlanul a határhaszon-iskolát, az egyéni javak mellett helyt adott a közjavaknak is. A munkabér magyarázatául sem fogadta el a határtermelékenységi elméletet. Tökének a fizikai javakat tekintette, a tőkefogalom immaterializációját valló nézetekkel szemben. Ebben ütközött 
Heller nézeteivel. Nem hitt a tökéletes piacokban, úgy látta, belső ellentmondást rejt magában a magára hagyott piac, és tendencia van a monopolhelyzetek kialakulására. Úgy vélte, semleges pénz nincs. A metallizmus híve volt, a bankjegyet nem tekintette pénznek. A konjunkturális ingadozásokat a gazdaság természetes jelenségének tartotta, de úgy gondolta, az állam által ,igazgatott pénzzel” a súlyosabb válságok elkerülhetőek... Az állami beavatkozást a gazdasági életben szükségesnek vélte, a „neoszocializmus” elöretörésével azonban (ezen a náci gazdaságpolitikát értette) inkább a beavatkozás korlátozására helyezte a hangsúlyt. Munkásságában sok ortodox, de ugyanakkor néhány elöremutató elem is van. Mindketten az MTA tagjai lettek.

Varga István pályája meg egyenesen példa arra, hogy nagy egyéniségeink a közösség szolgálatát mindenek elé helyezték, félretéve még az ideológiai kérdéseket és a személyes sérelmeket is. Varga István a Magyar Gazdaságkutató Intézet megszervezésével kezdte pályafutását. Az intézet egyik legjelentősebb és talán máig is a legismertebb, saját korában nemzetközi elismerést is kiváltó müve a nemzetijövedelem-számitás. Ez Varga István és Matolcsy Mátyás nevéhez füződik. 1944. március végén azonban a nácik németellenes összeesküvés vádjával letartóztatták és elhurcolták, 13 hónap raboskodás után szabadult. 1945 után az MTA levelező, majd igazgatótanácsi tagjává választotta. 1946-tól az Anyag és Árhivatal elnöki tisztét látta el. Ez évben jelent meg A magyar valutacsoda címủ írása, amelyben az új forint megteremtésének folyamatát írta le. Varga István volt „a magyar gazdasági csoda”, az erős forint megteremtője. Ezt a Kommunista Párt kisajátította, mint politikai eredményt. A gondos kutatás azonban bebizonyította, hogy egyértelmüen Varga munkáján alapult a megoldás. „Hálából” a kommunisták minden posztjáról kipenderítették. 1949-ben őt is, mint Hellert és Navratilt, megfosztották címeitől. Az 1956-os forradalom napjait követően, a felkelés fegyveres leverése után azonban a Kádár-kormány belátta, hogy a dolgok nem mehetnek a régi kerékvágásban. Gazdaságirányítási reformokra van szükség. „Előhúzták” tehát a jeles polgári közgazdászt, és felkérték, hogy legyen a Közgazdasági Szakértői Bizottság vezetője. Varga István habozás nélkül elvállalta. Nem a sérelmeit nézte, hanem segíteni próbált meggyötört hazájának. Elvei később az 1968-as reformokban valósultak meg - legalábbis részben.

Polányi Mihály, a jeles filozófus, gazdasági nézeteiben erősen szabadpiacpárti volt, testvérével, Polányi Károllyal ellentétben, aki baloldali közösségi közgazdászként jellemezhető. Ö az állam szerepvállalását igen fontosnak tartotta. Ugyanakkor kifejezett idealista volt, a demokrácia rendíthetetlen híve. A Rákosi-diktatúra mélyen elkeserítette. 1956-ra azonban rendkívül büszke volt. (Úgy fogalmazott, a forradalom visszaadta a haladásba vetett hitét, és egyben hazát is adott neki.) Voltak az idegenbe szakadt magyar társadalomtudósok között a katolikus egyház társadalmi tanítását feldolgozó tudósok, mint a 
jezsuita Muzslay István. Ez utóbbi munkássága azért időszerű, mivel korunkban a szubszidiaritás, a helyi közösségek szerepe a nemzetközi irodalomban is egyre nagyobb hangsúllyal jelenik meg. Kívánatos lenne, ha a mai gazdaságpolitikában a szubszidiaritás ismét megfelelő hangsúlyt kapna. Scitovsky Tibor pedig rendkívül fontos üzenetet fogalmazott meg a mának. Az örömtelen gazdaság címủ híres mủvében rámutatott, hogy a tudomány az emberért van, $\mathrm{s}$ olyan körülmények megteremtését kell segítenie, amelyben a társadalom tagjai boldog emberek lehetnek.

Nem feledkezhetünk el nagy, magyar származású közgazdáink között Lámfalussy Sándorról, a nemrég elhunyt jeles pénzügyi szakértőröl. Fontos rámutatni arra, hogy bár ő az „euró atyja”, nagyon jól látta, mennyire a politika determinálta az euró megszületését, és hogy ez milyen problémákat keletkeztetett. (Lásd korunk görög válságát.) Lámfalussy a nemzetközi pénzügyeket is éles kritikával szemlélte. Már a 2008-as válság előtt bírálta a nyakló nélküli liberalizálást, amely a hatalmas, világméretủ pénzügyi válságot kiváltotta. Javasolta, térjünk vissza a nemzetközi tőkemozgás egy korlátozottabb formájához, a Bretton Woods-i korlátozott konvertibilitáshoz. Hiszen a nemzetközi forró pénzek országokat dönthetnek romlásba (mint például a híres magyar tőzsdespekuláns, Soros György angol fonttal kapcsolatos lépései, vagy a Malajziát tönkretévő tőkemenekülés). Ebben ma már nincs egyedül, sok jeles pénzügyi szakértő van hozzá hasonló véleményen.

Mondanivalónkat mindenesetre tömören összefoglalhatjuk egy Csokonai parafrázisban: „az is bolond, aki poétává [közgazdásszá] lesz Magyarországon!”

Tehetséges társadalmunk azon tagjai ugyanis, akik a 20. században hazánkban akarták müvelni pályájukat, nagyon eltérő sorsot értek meg, azokhoz képest, akik emigrációba mentek, vagy oda kényszerültek. Míg az itthon maradottak jelentős részét tönkretette a fasizmus és a kommunizmus, addig az új hazát választók ragyogó karriert futottak be a világban. Lehet, hogy ez így túl sarkos állításnak tünik. Az életsorsok azonban, amelyeket fentebb láthattunk, elegendő számúak ahhoz, hogy ilyen általánosságban fogalmazzunk. Ez az, amin változtatnunk kell: legyen adott a tehetséges emberek számára itthon, a hazai boldogulás lehetősége!

\section{IRODALOM}

Balassa B. (1990): Nemzetközi kereskedelem és gazdasági növekedés. Budapest: Közgazdasági és jogi Könyvkiadó

Gyurgyák J. (szerk.) (1986): Polányi Károly. (Magyar szociológiatörténeti Füzetek 2.) Budapest: Szabó Ervin Könyvtár, https://library.hungaricana.hu/hu/view/FSZEK_SzociologiaiBiblio_8/?pg=0\&layout $=\mathrm{S}$ 
Hüttl A. (2012): A nemzeti jövedelem Fellner Frigyes korában - mai szemmel. Statisztikai Szemle, 90, 11-12, 1090-1099. http://www.ksh.hu/statszemle_archive/2012/2012_11-12/2012_11-12_ 1090.pdf

Káldor M. (1989): Gazdaságelmélet és gazdaságpolitika. Budapest: Közgazdasági és Jogi Könyvkiadó

Mányó Váróczi V. (2016): Varga István, a tudományszervező és a gazdaságpolitikus. PhD-értekezés. Budapest: PPKE, DOI: 10.15774/PPKE.BTK.2016.006, https://bit.ly/32uLxSc

Mátyás A. (szerk.) (1994): Magyar közgazdászok a két világháború között. Budapest: Akadémiai Kiadó

Schlett A. (é. n.): A boldogságkeresés útvesztői. (kézirat)

Scitovsky T. (1990): Örömtelen gazdaság. Budapest: Közgazdasági és Jogi Könyvkiadó

Sipos B. (1990): Heller Farkas. Budapest: Akadémiai Kiadó

Szabó K. (2002): Megemlékezés. Scitovsky Tibor. Magyar Tudomány, 9, 1252-1255. http://www. matud.iif.hu/02sze/szabo.html 